\title{
NASA explores scope for far-flung fix
}

\section{HONOLULU, HAWAII}

Researchers credit servicing missions involving astronauts with rescuing the Hubble Space Telescope and keeping it alive for the past 17 years. But an idea to create a similar, if simpler, capability for Hubble's successor is raising eyebrows among project scientists, who fear it will be impractical and expensive.

The James Webb Space Telescope (JWST), currently scheduled for launch in 2013, will make infrared observations from a position in space 1.5 million kilometres from Earth. That puts it farther away than Hubble, which sits in low-Earth orbit just 600 kilometres away, within easy reach of the shuttle. So the JWST was designed assuming that it would fly without any servicing - by astronaut or robot - for its five-to-ten-year career.

But Edward Weiler, head of NASA's Goddard Space Flight Center in Greenbelt, Maryland, which manages the JWST, has indicated that there may be scope for a manned mission to service or make simple repairs to the telescope.

"Wouldn't it make sense to ensure that astronauts could go to the telescope if they could fix it?"

"It might be valuable if astronauts could fly to the JWST to do something that was a critical, but easy fix," says Weiler, "like opening a stuck antenna." Weiler, who used to be NASA's science chief, floated the idea of attaching a

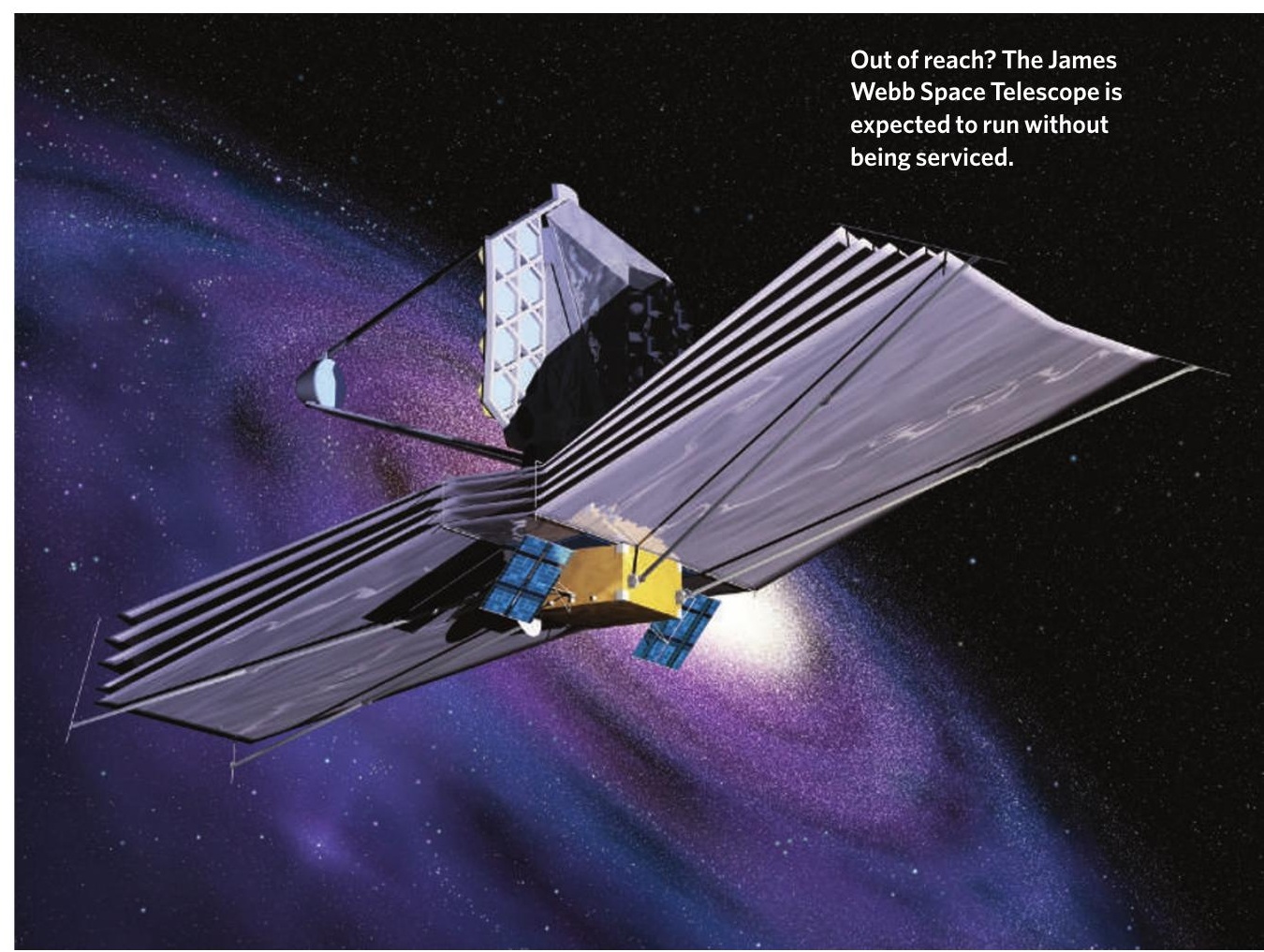

docking port to the telescope to allow a future mission to hook up.

But the concept got a chilly reception last week at the American Astronomical Society's biannual meeting in Honolulu, Hawaii. When the JWST was being developed, it seemed 岕 impossible that it would ever receive guests it will be well beyond the reach of the shuttle. Only the decision to develop the Orion crew exploration vehicle, due to replace the shuttle

\section{DNA reveals how the chicken crossed the sea}

The discovery of chicken bones with Polynesian DNA at an archaeological site in Chile has added hard, physical evidence to the controversial theory that ancient seafarers from the south Pacific visited the New World long before Columbus.

When the Spanish conquistador Francisco Pizarro first visited Peru in 1532 , he noted the importance of chickens in the daily lives and religious rituals of the Incas. But how the birds got there was a mystery. Chickens were first domesticated in Asia, and their absence from archaeological sites in the Americas indicates that they were not carried by migrating peoples over a land bridge from Asia to Alaska.

One alternative theory - that

Polynesians visited the Americas, bringing livestock with

them and perhaps

influencing cultural

and technological

development in the

region - has long been disparaged

by mainstream archaeologists, as

it has largely been supported by

supposition rather than evidence.

So Alice Storey of the University of Auckland, New Zealand, was not particularly enthusiastic when a colleague in Chile asked her to sequence DNA from a trove of ancient chicken bones he had excavated at El Arenal, a site occupied between 700 and 1390 AD, to see if their origins could be traced to the Pacific islands. "I

'It's essentially unequivocal evidence." thought, 'Well, we'll give it a go'," she says.

Storey and her team reconstructed a 400-

base-pair fragment of mitochondrial DNA from both the Chilean bones and chicken bones excavated on five archipelagos in Polynesia. Mitochondrial DNA doesn't mutate much and so is useful for tracing evolutionary lines. The Chilean sequences were identical to those from prehistoric sites in Tonga and Samoa (A. A. Storey et al. Proc.
Natl Acad. Sci. USA doi:10.1073/ pnas.0703993104; 2007).

Radiocarbon analysis dated the bones to between 1304 and 1424 $A D$, firmly before Europeans arrived on the east coast of South America in the 1500s. The same sequences are also present in the modern-day Araucana chicken, an odd Chilean breed that has tufted 'ears', lays blue eggs and lacks a tail.

The study has left the research community cautiously optimistic that hard evidence for migration of Polynesians has been found. Jaime Gongora, a molecular geneticist at the University of Sydney, Australia, says the paper is a significant 
after its retirement in 2010 and take astronauts back to the Moon, puts the telescope within reach. "If Orion is available, and we have a really simple, but significant problem on the JWST, wouldn't it make sense to ensure that astronauts could go to the JWST if they could fix it?" asks Weiler.

But the harsh radiation environment in deep space would probably make it far too dangerous for astronauts, says John Mather, the JWST's chief project scientist at Goddard. And a robot mission could probably do very little. It might be able to give the satellite a good shake to loosen a stuck solar panel, says Mather, but would be unlikely to cope with more complex tasks. And in its repair efforts, it might dirty the telescope's outer mirrors.

Mather says the JWST's team is now conducting a feasibility study to find out whether a docking port could be added. But given that it is unlikely that a problem so simple it could be fixed by a robot will surface during the mission, Mather says he is not keen to add something to the already grossly over-budget telescope. "If it costs more than a few thousand dollars," he says, "I'm not interested."

Repair missions to spacecraft closer to Earth than the JWST have so far been rare, but not unheard of. An orbiting mission to study the Sun was rescued by a service mission carried out by astronauts on the space shuttle Challenger in 1984. The first servicing mission to Hubble in 1993 fixed a critical error, installing a corrective optics system to fix the telescope's blurry vision. It has since been serviced a further three times.

Geoff Brumfiel

\section{Disgraced official was paid work bonus}

Further troubling reports have surfaced in the case of a disgraced US official accused of political interference in the workings of the Endangered Species Act. It has been disclosed that Julie MacDonald, former deputy assistant secretary for fish, wildlife and parks at the Department of the Interior (DOI), received a performance award of nearly $\$ 10,000$ in 2005 . Yet the report of an investigation into her conduct, released on 27 March this year, reveals that MacDonald violated federal regulations while in that position. She resigned on 1 May.

The report, by the DOI's office of inspector general, paints a portrait of a woman determined to minimize the Endangered Species Act's effect on the economy. It includes evidence from colleagues that she heavily edited science reports from the field despite having no formal scientific training, and bullied and intimidated field scientists into producing documents along the lines she wanted.

Observers say the case highlights how appointees of President George W. Bush can and have pushed political agendas within federal agencies. "She was a little bit more overt and transparent and shameless about her political antics and dealings, but she was not a lone ranger," says Jamie Rappaport Clark, executive vice-president of the environmental group Defenders of Wildlife in Washington DC and former director of the US Fish and Wildlife Service.

MacDonald was also chastised for sharing "nonpublic information with private sector sources", including a nonprofit lobby group called the California Farm Bureau Federation; the Pacific Legal Foundation, a law firm that represents development interests; and a friend from an online game. The report outlines how she sent internal departmental documents to a friend in the game World of Warcraft "to have another set of eyes give an unfiltered opinion of them". MacDonald could not be reached for comment by Nature.

The latest chapter comes from Steve Davies, editor of the newsletter Endangered Species \& Wetlands Report. Davies learned through a Freedom of Information Act request that MacDonald received a Special Thanks for Achieving Results award of $\$ 9,628$ in March 2005, during the period covered by the investigation. The DOI will not detail the reasons for the award; it says the justification is included in her performance evaluation, which is private.

Meanwhile, Democrats in Congress are investigating MacDonald for her role in removing the Sacramento splittail fish from the endangered species list. MacDonald owns a farm in a floodplain that is a habitat for the fish, according to an investigation by the Contra Costa Times, a newspaper in California. Emma Marris

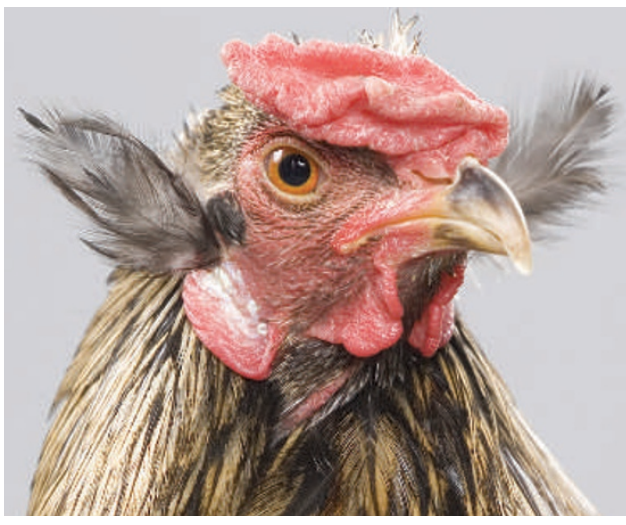

It's all relative: Chile's Araucana chicken shares its DNA with ancient birds from Polynesia.

contribution to the field, but warns that the small fragments obtained from ancient DNA may tell only part of the story. The final verdict will require more extensive DNA data to make a full family tree of both modern and ancient breeds, he says.

Archaeologist Terry Jones at California Polytechnic State University in San Luis Obispo, who has studied prehistoric Polynesian contact in the New World, is less circumspect. "It's essentially unequivocal evidence," he says.

Evidence of contact between the communities has been put forward in the past. In 1947, Thor Heyerdahl famously filmed his journey by raft from Peru across the Pacific to try to prove that South Americans could have settled the Pacific islands; although the theory was at odds with much of the evidence.

More recently, Jones, along with Kathryn Klar at the University of California, Berkeley, has argued that the Polynesians introduced complex fish hooks and sewn plank canoes to the Chumash and Gabrielino Indians in southern California and the Mapuche Indians in Chile (K. A. Klar and T. L. Jones Am. Antiquity 70,
457-484; 2005). Others argue that Polynesians must have visited the tropical coast of South America in order to bring back the sweet potato and the bottle gourd. The voyage to South America is no more daunting than other trips Polynesians are known to have made.

Even so, one of the co-authors on the chicken study, Atholl Anderson at the Australian National University, Canberra, is wary of overestimating the extent of this cultural diffusion without further study. Although the chickens provide hard evidence of transoceanic contact, the evidence that large-scale cultural exchange occurred remains largely circumstantial, he says.

Brendan Borrell 